\title{
Rheological Properties of Monodisperse Latex
}

\author{
by
}

\author{
Shigeki Mitaku, Toshiya Ohtsuki, and Koji Okano \\ (Department of Applied Physics, Faculty of Engineering, \\ University of Tokyo, Bunkyo-ku, Tokyo 113)
}

\begin{abstract}
Steady flow properties of the ordered monodisperse polystyrene latex have been measured. The ordered latex has a yield stress of about $1 \mathrm{dyne} / \mathrm{cm}^{2}$ and the yield stress $\sigma$ is related to the rigidity $G$ as $\sigma=1.7 \times 10^{-3} G$. These facts suggest that the ordered monodisperse latex is a "crystal" which undergoes a plastic deformation by the same mechanism as the ordinary crystals. The salt concentration dependence of the steady flow viscosity in the disordered latex is also discussed.
\end{abstract}

\section{単分散ラテックスの 流 動 特 性}

\author{
美宅成 樹・大 月 俊 也・岡 野 光 治*
}

（原稿受理：1978年12月21日）

\section{1. 緒言}

粒子径のよくそろったポリスチレン球の水分散系（単分散ポリ スチレンラテックス) は粒子濃度が高く, 分散媒中の塩濃度が低い という条件下で結晶的な規則構造をとることが知られている(1),2). この規則構造は粒子間の静電的反発力のみによって形成されたも のであるととが明らかにされており ${ }^{3) ~ 5)}$, 規則構造形成における 分子（粒子）間反発力の重要性を示唆する物質として固体物理学 の立場から注目されている6). 我々はてれまでての結晶的な規則 構造の粘弾性測定を行ってきたが, その結果規則構造形成に伴い 約 $10^{3} \mathrm{dyne} / \mathrm{cm}^{2}$ のずり弾性率が観測されることを見いだした ${ }^{7)}$. すなわち, 単分散ラテックスの規則構造は単に構造だけでなく, 力学物性の面でも通常の結晶之同様の性質を持っていると考えら れる。

一方, 単分散ラテックスは大きさの一様な球形粒子の分散系で あるので, 分散系のレオロジーを研究する上でも格好の材料であ る. 実際に単分散ラテックスの流動特性の研究は種々行われてい るが $\left.{ }^{8} \sim 10\right)$, 単なる剛体球分散系のレオロジーとしては解釉しが たい結果が得られている。例えば，Krieger 等は粒子濃度が $5 \%$ 以上の単分散ラテックスについて降伏応力が観測されることを見

\footnotetext{
* 東京大学工学部 東京都交京区本郷
}

いだしている9 . これらのことを考慮に入れて，本研究では単分 散ラテックスの規則構造の流動特性が結晶塑性（流動）という見 地から理解できるのではないかと考え, 非常に低いずり速度での 粘度測定を行った. その結果, 規則構造は降伏応力を伴うビンガ ム型の流動特性を示し, 定量的にも通常の結晶塑性と類似してい ることがわかった。

\section{2. 方法と試 料}

流動特性は低ずり速度, 低ずり応力での測定ができる同軸二重 円筒型の粘度計により測定した ${ }^{11)}$ 。乙れは Zimm-Crothers 型粘 度計 ${ }^{12)}$ を基礎として, 単分散ラテックスの测定のために改良を施 した装置である．主な特徵は, 第一にずり応力を $10^{-3}-1.5 \mathrm{dyne} /$ $\mathrm{cm}^{2}$ の範囲で連続的に変えられる。第二に, $5 \times 10^{-5}-60 \mathrm{sec}^{-1}$ の 範囲のずり速度が測定できる、第三に，単分散ラテックスのよう な不透明な試料でも測定できる。また, 測定中試料の表面が乾燥 しやすいので外筒にふたをし, 手早く測定した。測定は全部 $30^{\circ} \mathrm{C}$ で行った。

試料の単分散ラテックスは RCA 基礎研究所の藤田氏に提供し ていただいた。ポリスチレン球の直径は $1,250 \AA$ ，その分散が約 $50 \AA$ であった。また，一粒子当たり平均 1,240 個の素電荷を持っ ており，粒子同士は静電的に反発し合っている。体積分率 $11.7 \%$ 
の試料を用いたが，乙れは平均粒子間距離にして $2,300 \AA$ に対応 しており，粒子間のファンデアヴァールス引力は無視できるほど 小さい。規則構造に伴う虹彩色を示している単分散ラテックスに 径々に $\mathrm{KCl}$ を加えながら 流動特性の変化を測定した. $\mathrm{KCl}$ 濃度 が $160 \mu \mathrm{M}$ のところで試料の虹彩色は消え乳白色となり, 規則構 造の融解が観察により確かめられた。

\section{3. 結 果}

体積分率11.7\%のポリスチレンラテックスの流動特性をFig. 1 に示す. 単分散ラテックスの流動が分散媒中の塩濃度によって非 常に顕著に変化するのがわかる．可視光のブラッグ反射である虹 彩色が見られる $150 \mu \mathrm{M}$ 以下の $\mathrm{KCl}$ 濃度では明らかな降伏応力 が観測され，ビンガム型の流動曲線となっている。一方, $180 \mu \mathrm{M}$ $\mathrm{KCl}$ 以上では試料は既に虹彩色を示さず乳白色の無秩序な状態之 なっているが，乙のときはニュートン流動を示している. 単分散 ラテックスの構造形成と流動特性の変化との相関は非常によく, 降伏応力を伴う非ニュートン的な挙動が単分散ラテックスの結晶 的な構造によることは明らかである.

塩濃度に対する流動特性の依存性を更に細かくみるために, 降 伏応力および粘度の $\mathrm{KCl}$ 濃度依存性を示したのが Fig. 2 である. 降伏応力は約 $50 \mu \mathrm{M}$ 以下の塩濃度では $1.5 \mathrm{dyne} / \mathrm{cm}^{2}$ でほぼ一定 であるが， $50 \mu \mathrm{M}$ から $160 \mu \mathrm{M}$ の範囲で急激に減少し零になって いる。また，無秩序状態での粘度は塩濃度が十分高いところでは $1.3 \mathrm{cp}$ であるが, 塩濃度の減少とともに急激に増大している。同

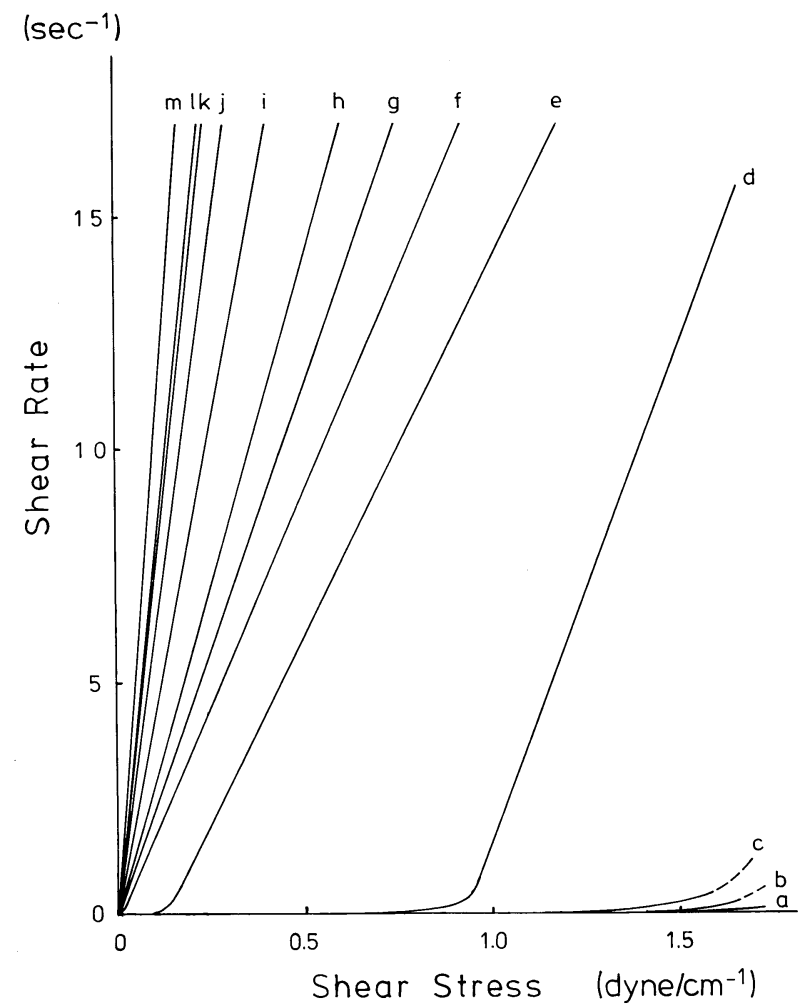

Fig. 1 Flow properties of monodisperse polystyrene latex as a function of $\mathrm{KCl}$ concentration in the solvent (a, $100 \mu \mathrm{M} ; \mathrm{b}, 120 \mu \mathrm{M} ; \mathrm{c}, 130 \mu \mathrm{M} ; \mathrm{d}, 140 \mu \mathrm{M} ; \mathrm{e}, 150$ $\mu \mathrm{M} ; \mathrm{f}, 160 \mu \mathrm{M} ; \mathrm{g}, 180 \mu \mathrm{M} ; \mathrm{h}, 200 \mu \mathrm{M} ; \mathrm{i}, 300 \mu \mathrm{M} ; \mathrm{j}$, $500 \mu \mathrm{M} ; \mathrm{k}, 1 \mathrm{mM} ; 1,2 \mathrm{mM} ; \mathrm{m}$, water).

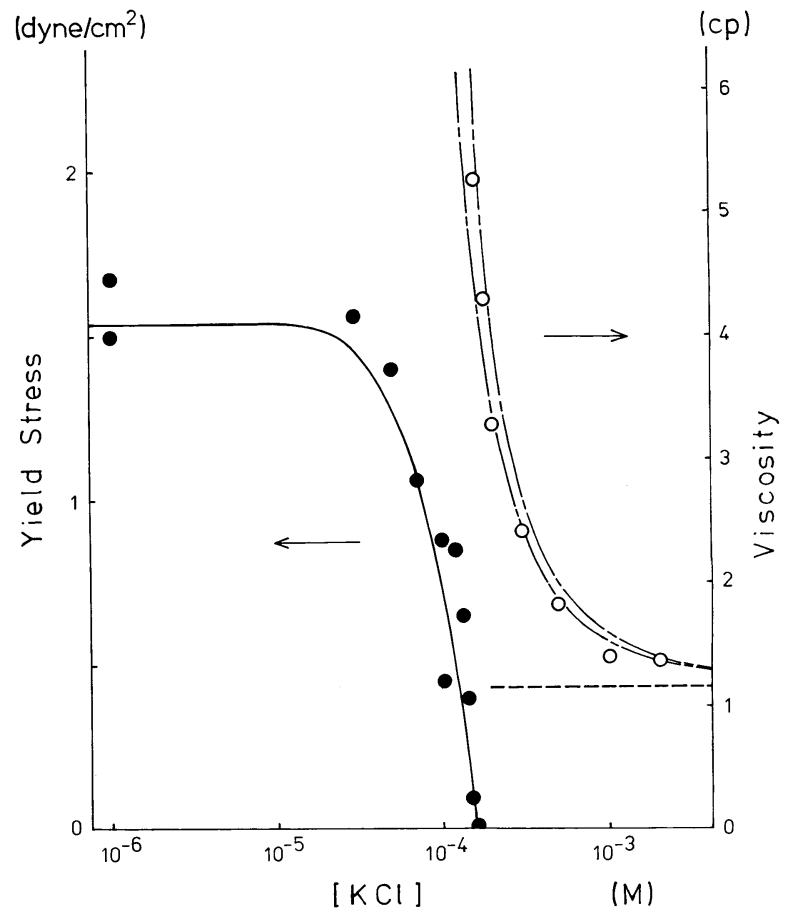

Fig. 2 Yield stress in the ordered phase and viscosity in the disordered phase of polystyrene spheres are plotted against $\mathrm{KCl}$ concentration in the solvent. Solid line is obtained from the rigidity $G$ according to the equation, $\sigma=1.7 \times 10^{-3} G$, in which $\sigma$ is the yield stress of latex. Dashed line is a dynamic viscosity at $40 \mathrm{kHz}$, and broken lines are theoretical curves of the steady flow viscosity.

じ試料について $40 \mathrm{kHz}$ の動的粘弾性 ${ }^{7)}$ 屯測定したが. 図中の実 線は動的剛性率の $\mathrm{KCl}$ 濃度依存性に $1.7 \times 10^{-3}$ を乗じたもので ある。剛性率と降伏応力は非常によく似た塩濃度依存性を示し, 降伏応力は剛性率より三桁小さいととがわかる。また，破線の動 的粘性率は $\mathrm{KCl}$ 濃度に対してほとんど不変であった。

\section{4. 討}

\section{論}

単分散ラテックスの規則構造が結晶と類似のものであるならば, その構造を安定に保つ有限の剛性率と降伏応力を持つはずである.

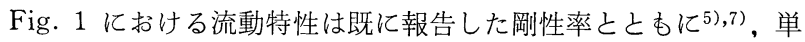
分散ラテックスの規則構造が本来の意味での “結晶”であるとと を示していると考えられる，定量的には，降伏応力は単分散ラテ ックスの場合約 $1 \mathrm{dyne} / \mathrm{cm}^{2}$ で, 金属結晶などの場合の $10^{-8} \sim 10^{-9}$ 倍であり, 剛性率の $10^{3} \mathrm{dyne} / \mathrm{cm}^{2}$ もやはり通常の結晶の $10^{-8}$ 〜 $10^{-9}$ 倍である。一見, これらの值は結晶の物性としては小さすぎ るように思われるが, Fig. 2 に示した降伏応力之剛性率の間の関 係式

$$
\begin{aligned}
& \sigma=A G \\
& A=1.7 \times 10^{-3}
\end{aligned}
$$

は金属の結晶などにおいて一般的にみられる関係で， $A$ の值も金 属などの場合の $10^{-5} \sim 10^{-3}$ に一致している。乙のことは単分散 ラテックスの規則構造の流動が結晶の塑性変形と同様の機構で起 こっていることを示唆している. 蓮らの顕微鏡観察によれば単分 散ラテックスの結晶的な構造の中に多数の欠陥が認められている 
が14), 本研究の結果はこれらの格子欠陥の運動が通常の結晶にお けると同様に単分散ラテックスの規則構造の流動特性, 特にその 降伏応力を決めているととを示すあのと思われる.

一方, 無秩序状態の単分散ラテックスの定常流粘度は Fig. 2 に示す如く塩濃度に非常に強く依存しており, 塩濃度が低くなる ほど急激に増大している. その極限として塩濃度が $160 \mu \mathrm{M}$ のと ころで規則構造形成が起こり, 降伏応力が現れるわけである. こ のような塩濃度の効果は個々の粒子に対する電気粘性効果 ${ }^{15)}$ では 説明できず, 粒子間の静電的相互作用によると考えられる.ての ことは Fig. 2 亿破線で示した動的粘性率が塩濃度に全く依存し ないことからあ推論される.すなわち, 動的粘性率は $40 \mathrm{kHz}$ の ねじれ水晶振動子を用いて測定したが，乙の場合励起されたずり 波によって粒子が動く距離は平均粒子間距離よりはるかに小さく、 測定された動的粘性率の值屯個々の粒子と水之の間の粘性抵抗の みでほぼ説明できる5 .したがって, Fig. 2 の定常流粘度と動的 粘度の間の大きな差が粒子間の静電相互作用によるととは明らか である.

この静電相互作用による定常流粘度の異常な増大を理論的に説 明することは困離であるが, 近似的には各粒子を静電ポテンシャ ルによりデバイの長さだけ半径が大きくなった剛体球とみなすて とにより取り扱うことができる. かなり高濃度まで分散系の粘度 をよく表現していると言われるブリンクマンの粘度式

$$
\eta_{\mathrm{rel}}=(1-\phi)^{-5 / 2}
$$

に扔いて，体積分率 $\phi$ の代わりに有効体積分率

$$
\phi^{*}=\phi(1+\lambda / \kappa a)^{3}
$$

を代入して粘度を求めるわけである. こてで, $1 / \kappa$ はデバイの長 さ, $a$ は粒子の半径, $\lambda$ は 1 亿近い定数である. このようにして 得られた無秩序状態における粘度の塩濃度依存性が Fig. 2 の一 点鎖線である.二本の線はそれぞれ規則構造形成が起こる $160 \mu \mathrm{M}$ の塩濃度で, $\phi^{*}=0.5$ および 0.55 になる場合を示しており, 有 効体積分率 $0.5 \sim 0.55$ で剛体球の結晶化が起こることを示したア ルダー等の計算機実験に対応した条件により入を決定したもので ある. 粒子間相互作用を非常に大雑把に剛体球ポテンシャルで近 似したにあかかわらず, 得られた曲線はよく測定值と一致してお
り，無秩序状態での流動特性において，各粒子をデバイの長さだ け半径の大きな剛体球とみなす近似はかなりよいのではないかと 思われる。

\section{文献}

1) Luck, V.W., M. Klier, and H. Wesslau, Die Naturwissenschaften, 14, 485 (1963).

2) Hachisu, S., Y. Kobayashi, and A. Kose, J. Colloid Interface Sci., 42, 342 (1973).

3) Wadati, M., and M. Toda, J. Phys. Soc. Japan, 32, 1147 (1972).

4) Fujita, H., and K. Ametani, Japan. J. Appl. Phys., 16, 1091 (1977).

5) Ohtsuki, T., S. Mitaku, and K. Okano, Japan. J. Appl. Phys., 17, 627 (1978).

6）和達三樹, 巨勢朗, 戸田盛和, 科学, 42, 646 (1972).

7) Mitaku, S., T. Ohtsuki, K. Enari, A. Kishimoto, and K. Okano, Japan. J. Appl. Phys., 17, 305 (1978).

8) Saunders, F.L., J. Colloid Sci., 16, 13 (1961).

9) Krieger, I.M., and M. Eguiluz, Trans. Soc. Rheol., 20: 1, 29 (1976).

10) Brodnyan, J.G., and E.L. Kelley, J. Colloid Sci., 20, 7 (1965).

11) Mitaku, S., T. Ohtsuki, K. Hirakawa, H. Handa, and K. Okano, J. Fac. Eng. Univ. Tokyo(B), XXXIV, 605 (1978).

12) Zimm, B.H., and D.M. Crothers, Proc. Natl. Acad. Sci., 48, 905 (1962).

13) Nabbaro, F.R.N., Proc. Phys. Soc., 59, 256 (1947).

14) Kose, A., M. Ozaki, K. Takano, Y. Kobayashi, and S. Hachisu, J. Colloid Interface Sci., 44, 330 (1973).

15) Booth, H.H.F., Proc. Roy. Soc. London, A203, 533 (1950). 